\title{
PENGARUH TERAPI SOMATIS ISOLASI TERHADAP PERUBAHAN PERILAKU KEKERASAN PADA PASIEN SKIZOFRENIA
}

\author{
Effects Somatic Isolation Therapy on Violent Behavior Alteration in Schizophrenia \\ Patient
}

\author{
Desak Made Ari Dwi Jayanti ${ }^{1}$, Ni Kadek Yuni Lestari ${ }^{2}$, Ni Nyoman Meira Sugiantari ${ }^{3}$ \\ ${ }^{1}$ Departemen Keperawatan Jiwa, STIKES Wira Medika Bali, Denpasar, Bali, Indonesia \\ ${ }^{2}$ Departemen Keperawatan Medikal Bedah, STIKES Wira Medika Bali, Denpasar, Bali, Indonesia \\ ${ }^{3}$ Program Studi S1 Keperawatan, STIKES Wira Medika Bali, Denpasar, Bali, Indonesia \\ Korespondensi: djdesak@gmail.com
}

\begin{abstract}
ABSTRAK
Skizofrenia merupakan salah satu gangguan jiwa berat yang ditandai dengan perilaku kekerasan. Perilaku kekerasan merupakan respon terhadap stresor yang dihadapi oleh seseorang, baik pada diri sendiri, orang lain maupun lingkungan, secara verbal maupun non verbal. Penelitian ini bertujuan untuk mengetahui pengaruh terapi somatis isolasi terhadap perubahan perilaku kekerasan. Jenis penelitian ini adalah pre-eksperimen pendekatan one-group pre-testposttest design dengan teknik sampling purposive. Jumlah sampel sebanyak 20 orang. Setelah dilakukan pengamatan didapatkan hasil perilaku kekerasan pasien skizofrenia sebelum diberikan terapi somatis isolasi $100 \%$ responden dengan perilaku kekerasan risiko tinggi, setelah diberikan terapi somatis isolasi terbanyak (85\%) dengan perilaku kekerasan risiko sedang. Hasil uji wilcoxon sign rank didapatkan $\mathrm{p}=0,000<0,05$ yang berarti ada pengaruh yang signifikan antara pemberian terapi somatis isolasi terhadap perubahan perilaku kekerasan pada pasien skizofrenia. Disarankan pada pelaksanaan terapi somatis isolasi sesuai dengan SPO yang ditetapkan.
\end{abstract}

Kata kunci : terapi somatis isolasi; perilaku kekerasan; skizofrenia

\begin{abstract}
Schizophrenia is one of the major mental disorders characterized by violence behavior. Violence behavior is a response to the stressors faced by a person, on yourself, others people and the environment, verbally and non-verbally. This study aimed to determine the effects somatic isolation therapy on violent behavior alteration. The type of this research is preexperiment with approach one-group pre-test-posttest design, with sampling technique is purposive. Total sample is 20 peoples. The result of violence behavior of schizophrenia patients before somatic isolation therapy was given $100 \%$ with high risk of violence behavior, after being given somatic isolation therapy (85\%) with moderate risk of violence behavior. Wilcoxon Sign Rank Test results obtained $p=0,000<0.05$ which means there is a significant effect between somatic isolation therapy to changes violence behavior in schizophrenic patients. Suggested on the implementation of somatic isolation therapy is accordance with standard operating procedure.
\end{abstract}

Keywords: somatic isolation therapy; violence behavior; schizophrenia 


\section{PENDAHULUAN}

Kesehatan jiwa adalah suatu bagian yang tidak terpisahkan dari kesehatan atau bagian integral dan merupakan unsur utama dalam menunjang terwujudnya kualitas hidup manusia. Gangguan jiwa yang terjadi di era globalisasi dan persaingan bebas cenderung meningkat. Berbagai hal seperti kegagalan dalam hidup, kehilangan orang yang dicintai, putusnya hubungan sosial, masalah dalam pernikahan, tekanan dalam pekerjaan, krisis ekonomi merupakan faktorfaktor pemicu yang menimbulkan stress dan dapat meningkatkan risiko menderita gangguan jiwa (Prabowo, 2015). Menurut data WHO (World Health Organization) pada tahun 2016 terdapat sekitar 35 juta orang terkena depresi, 60 juta orang terkena bipolar, 21 juta terkena skizofrenia serta 47,5 juta terkena demensia. Penderita skizofrenia terdiri dari 12 juta laki-laki dan 9 juta perempuan. Skizofrenia juga biasanya dimulai lebih awal pada pria. Skizofrenia ditandai dengan distorsi dalam berpikir, persepsi, emosi, bahasa, rasa diri dan perilaku. Lebih dari $50 \%$ penderita skizofrenia tidak mendapatkan perawatan yang tepat (Kemenkes, 2016).

Hasil riset kesehatan dasar tahun 2013 mencatat bahwa prevalensi gangguan jiwa berat di Indonesia mencapai 1,7 per mil, artinya 1-2 orang dari 1.000 penduduk Indonesia mengalami gangguan jiwa berat (Kemenkes, 2013). Data tahun 2015, di Indonesia didapatkan bahwa $70 \%$ dari 2,5 juta jiwa penderita skizofrenia melakukan perilaku kekerasan. Bentuk perilaku kekerasan yang dilakukan bisa melukai diri sendiri, melukai orang lain, merusak lingkungan rumah, lingkungan masyarakat dan mengancam nyawa orang lain (Prabowo, 2015). Data prevalensi penderita gangguan jiwa berat di Provinsi Bali berada pada urutan ke tiga setelah Provinsi Daerah Istimewa Yogyakarta, Aceh dan Sulawesi Selatan, yaitu mencapai 2,3 per mil, artinya 2-3 orang dari 1.000 penduduk di Bali mengalami gangguan jiwa, hal ini menunjukkan kasus gangguan jiwa berat di Provinsi Bali lebih besar dari data nasional di Indonesia (Kemenkes, 2013).

Berdasarkan data laporan tahunan 2017

Rumah Sakit Jiwa (RSJ) Provinsi Bali, jumlah pasien yang dirawat dengan diagnosa skizofrenia sebanyak 4080 orang yang terdiri dari 2756 laki-laki dan 1324 perempuan. Berdasarkan data tersebut ratarata jumlah pasien skizofrenia yang di rawat inap setiap bulannya adalah sebanyak 340 orang.

Salah satu gangguan jiwa yang sering ditemukan dan dirawat yaitu skizofrenia (Maramis, 2008). Hampir 80\% pasien skizofrenia mengalami kekambuhan berulang kali (Amelia, 2013). Menurut Faisal (dalam Prabowo 2014) skizofrenia adalah kepribadian yang terpecah antara pikiran, perasaan dan perilaku. Kondisi ini berarti apa yang dilakukan tidak sesuai dengan apa yang dipikirkan atau dirasakannya. Karakteristik yang sering ditemukan pada pasien skizofrenia adalah adanya gangguan emosi yang dapat berupa ketakutan, kecemasan, depresi dan kegembiraan. Kecemasan pada pasien skizofrenia dapat berupa gangguan parathimi atau yang seharusnya menimbulkan rasa senang dan gembira, pada pasien malah timbul rasa cemas, sedih dan marah yang bisa menimbulkan perilaku kekerasan (Direja, 2011).

Perilaku kekerasan merupakan respon terhadap stresor yang dihadapi oleh seseorang, yang ditunjukkan dengan perilaku aktual melakukan kekerasan, baik pada diri sendiri, orang lain maupun lingkungan, secara verbal maupun non verbal, bertujuan untuk melukai orang lain secara fisik maupun psikologis (Yosep, 2009). Perilaku kekerasan banyak dilakukan oleh kelompok umur dewasa yaitu 25-45 tahun sebanyak 63,14\% (Sira, 2011) dengan tingkat pendidikan paling banyak yaitu SMA $(59,4 \%)$ (Noviyanti, 2013) dan status perkawinan yaitu kawin $(53,3 \%)$ (Nusantari, 2016).

Dampak yang dapat ditimbulkan oleh pasien yang melakukan perilaku kekerasan adalah bisa membahayakan diri sendiri, orang lain maupun merusak lingkungan (Keliat, 2016). Menurut Prabowo (2014), perilaku kekerasan terdiri dari perilaku kekerasan secara verbal maupun fisik. Perilaku kekerasan secara verbal sebagai suatu bentuk perilaku atau aksi agresif yang diungkapkan untuk 
Desak Made Ari Dwi Jayanti: Pengaruh Terapi Somatis Isolasi Terhadap Perubahan Perilaku Kekerasan Pada Pasien Skizofrenia

menyakiti orang lain, dapat berbentuk umpatan, kata-kata yang kotor, berbicara dengan nada keras kasar dan ketus, ejekan dan ancaman melalui kata-kata. Perilaku kekerasan Perilaku kekerasan secara fisik dapat berbentuk meninju, menendang, mengancam orang lain dengan senjata dan menyerang orang lain. Berdasarkan hal tersebut, maka untuk menghindari dampak yang timbul diperlukan suatu tindakan pelayanan kesehatan.

Jenis pelayanan kesehatan yang biasa dilakukan pada penanganan pasien skizofrenia dengan perilaku kekerasan adalah terapi somatis isolasi, pemberian medika mentosa, pengikatan dan pembentukan tim kritis (Stuart, 2013). Hasil penelitian yang dilakukan oleh Downey (2013) didapatkan data bahwa alasan paling sering mengapa pasien mendapat terapi somatis isolasi adalah karena perilaku kekerasan sejumlah 122 dari 126 orang atau sebayak $96,8 \%$.

Menurut Direja (2011) terapi somatis isolasi atau seklusi adalah tindakan yang dapat dilakukan kepada pasien perilaku kekerasan tanpa adanya risiko tinggi bunuh diri, pasien dengan gangguan sosial dan pasien yang membutuhkan observasi untuk masalah fisik. Pelaksanaan terapi somatis isolasi adalah dengan mengurung klien dalam ruangan khusus (Direja, 2011). Menurut penelitian Valkama (2010), pasien yang telah mendapatkan terapi somatis isolasi menyatakan bahwa terapi ini memberi efek menenangkan pada mereka karena memberi mereka lingkungan yang lebih aman dan nyaman ketika perilaku kekerasan mereka tidak bisa dikontrol. Lingkungan yang aman dan nyaman membantu mempercepat penurunan derajat perilaku kekerasan mereka.

Berdasarkan hasil penelitian Saseno (2013) menyatakan bahwa terjadi penurunan perilaku kekerasan setelah diberikan terapi somatis restrain dengan manset yaitu didapatkan hasil dari 38 responden yang sebelum tindakan ada pada kategori intensif 1, menurun ke intensif 2 yaitu sebanyak 29 responden $(76,3 \%)$ dan yang perilaku kekerasannya menurun ke intensif 3 sebanyak 9 responden $(23,7 \%)$.
Hasil studi pendahuluan di Ruang Intensive Psychiatric Care Unit (IPCU) Rumah Sakit Jiwa Provinsi Bali, diperoleh data bahwa jumlah pasien skizofrenia dengan masalah keperawatan perilaku kekerasan tiga bulan terakhir yaitu November dan Desember 2017 serta Januari 2018 adalah 143 orang dengan rata-rata perbulan sebanyak 48 orang. Ruang Intensive Psychiatric Care Unit (IPCU) Rumah Sakit Jiwa Provinsi Bali merupakan ruangan khusus dengan desain ruangan isolasi. Kapasitas ruangan tersebut adalah 20 tempat tidur. Ruangan ini diperuntukkan untuk perawatan intensive bagi pasien dengan perilaku agresif, risiko bunuh diri dan visum psikiatri.

Pasien yang diantar ke Rumah Sakit Jiwa Provinsi Bali kebanyakan dengan keluhan mengamuk. Tindakan keperawatan yang biasanya dilakukan di ketika pasien dalam kondisi gaduh gelisah adalah pemberian terapi somatis isolasi maupun restrain. Tindakan ini dipilih karena tidak memungkin memberikan terapi modalitas lain ketika pasien dalam kondisi gaduh gelisah. Terapi somatis isolasi dilakukan segera ketika pasien menunjukkan tandatanda akan melakukan perilaku kekerasan maupun setelah pasien melakukan perilaku kekerasan. Tindakan ini dilakukan tanpa mengukur derajat perilaku kekerasan sebagai tolak ukur untuk memulai dan mengakhiri tindakan terapi somatis isolasi. Pelaksanaan tindakan terapi somatis isolasi juga belum sesuai standar prosedur operasional.

Berdasarkan uraian diatas, maka perlu dilakukan penelitian tentang pengaruh terapi somatis isolasi terhadap perubahan perilaku kekerasan pada pasien skizofrenia di Ruang Intensive Psychiatric Care Unit (IPCU) Rumah Sakit Jiwa Provinsi Bali.

\section{TUJUAN PENELITIAN}

Penelitian ini bertujuan untuk mengetahui pengaruh terapi somatis isolasi terhadap perubahan perilaku kekerasan pada pasien skizofrenia di Ruang Intensive Psychiatric Care Unit (IPCU) Rumah Sakit Jiwa Provinsi Bali. 
Desak Made Ari Dwi Jayanti: Pengaruh Terapi Somatis Isolasi Terhadap Perubahan Perilaku Kekerasan Pada Pasien Skizofrenia

\section{METODE PENELITIAN}

\section{Desain}

Penelitian ini merupakan penelitian pre eksperimental dengan rancangan onegroup pre-test-posttest design.

\section{Populasi dan Sampel}

Populasi pada penelitian ini adalah seluruh pasien yang dirawat dengan diagnosa medis skizofrenia dan masalah keperawatan perilaku kekerasan yang dirawat di Ruang Intensive Psychiatric Care Unit (IPCU) Rumah Sakit Jiwa Provinsi Bali dengan jumlah rata-rata perbulan sebanyak 48 orang. Sampel dalam penelitian ini adalah pasien skizofrenia dengan masalah keperawatan perilaku kekerasan di Ruang Intensive Psychiatric Care Unit (IPCU) Rumah Sakit Jiwa Provinsi Bali sebanyak 20 sampel, dengan teknik pengambilan sampel dalam penelitian adalah non probability sampling jenis purposive sampling.

\section{Tempat dan Waktu Penelitian}

Penelitian ini dilakukan di Rumah Sakit Jiwa Provinsi Bali pada bulan Januari sampai Mei 2018.

\section{Instrumen dan Prosedur Pengukuran}

Instrument yang digunakan yaitu lembar observasi perilaku kekerasan.

\section{Analisa Data}

Analisis data pengaruh antara dua variabel digunakan Uji Wilcoxon Sing Rank Test.

\section{HASIL PENELITIAN}

Sebelum dilakukan uji bivariat, terlebih dahulu dilakukan uji normalitas data dengan menggunakan uji ShapiroWilk. Hasil uji Shapiro-Wilk menunjukkan bahwa nilai $\mathrm{p}$ value $0,001<$ p 0,05 maka data berdistribusi tidak normal.

Uji yang digunakan dalam penelitian ini adalah uji statistik Wilcoxon Sing Rank Test. Hasil analisis disajikan pada tabel 1 berikut :
Tabel 1

Identifikasi Perilaku Kekerasan pada Pasien Skizofrenia

\begin{tabular}{lccc}
\hline Variabel & Mean & $\begin{array}{c}\text { Standar } \\
\text { Deviasi }\end{array}$ & $\begin{array}{c}p \text { - } \\
\text { value }\end{array}$ \\
\hline Pre-test & 11.75 & 1.209 & \\
Post-test & 7.10 & 1.861 & 0.000 \\
Beda & 4.65 & 652 & \\
\hline
\end{tabular}

Berdasarkan tabel 1 diatas dapat diketahui hasil penelitian didapatkan $p$ value $=0,000<\mathrm{p} 0,05$ berarti hipotesis penelitian diterima artinya ada pengaruh yang signifikan antara pemberian terapi somatis isolasi terhadap perubahan perilaku kekerasan di Ruang Intensive Psychiatric Care Unit (IPCU) Rumah Sakit Jiwa Provinsi Bali.

\section{PEMBAHASAN}

Tanda dan gejala yang khas pada pasien skizofrenia yang dapat juga merugikan termasuk mencederai diri sendiri orang lain ataupun lingkungannya membuat tenaga kesehatan atau orang-orang di sekeliling pasien memberikan penanganan khusus untuk mengatasi perilaku tersebut. Penanganan yang sering dilakukan dilakukan di rumah sakit jiwa adalah terapi somatis isolasi. Hasil penelitian menunjukkan bahwa terdapat 67 dari 1000 orang pasien yang dirawat di rumah sakit jiwa di Amerika Serikat selama 10 tahun terakhir yang mendapatkan terapi somatis isolasi (Keliat, 2014).

Pasien dengan gangguan jiwa merupakan seseorang yang berisiko tinggi untuk melakukan tindakan kekerasan baik pada diri sendiri, orang lain, maupun lingkungannya. Perilaku kekerasan yang dilakukan pasien antara lain dalam bentuk kata-kata kasar sebanyak 60\%, melakukan tindakan kekerasan terhadap objek sebanyak 29\% dan melakukan kekerasan terhadap diri sendiri sebanyak 19\% (Keliat, 2014).

Menurut Howes (2013) isolasi adalah cara yang digunakan oleh psikiater terutama untuk mengelola perilaku agresif yang disebabkan oleh gangguan mental. Terapi somatis isolasi dirancang untuk memberikan lingkungan yang aman bagi pasien. Isolasi menunjukkan kondisi atau keadaan yang dipisahkan dari masyarakat 
Desak Made Ari Dwi Jayanti: Pengaruh Terapi Somatis Isolasi Terhadap Perubahan Perilaku Kekerasan Pada Pasien Skizofrenia

serta berada dalam keadaan terasingkan, sendirian di ruangan yang terkunci dan tidak bisa keluar dengan bebas. Terapi somatis isolasi paling sering digunakan dalam fase akut pengobatan kejiwaan terkait penggunaan obat dan skizofrenia. Terapi somatis adalah terapi yang diberikan pada pasien dengan tujuan mengubah perilaku maladaptif ke perilaku adaptif dengan melakukan tindakan dalam bentuk perlakuan fisik.

Otak memiliki bagian-bagian seperti hipotalamus, amigdala, hipokampus, talamus, serta korteks serebri yang berfungsi bersama-sama untuk memulai aktivitas motorik dan fungsional. Salah satu yang membantu pengiriman sinyal sensorik ke otak dan sinyal motorik ke otot adalah transmiter molekul kecil yang bekerja cepat. Neurotransmiter yang paling mempengaruhi sikap, emosi, dan perilaku seseorang antara lain adalah asetil kolin, dopamin, serotonin, epinefrin dan norepinefrin. Sistem norepinefrin dan sistem serotonin normalnya menimbulkan dorongan bagi sistem limbik untuk meningkatkan perasaan seseorang terhadap rasa nyaman, menciptakan rasa bahagia, rasa puas, nafsu makan yang baik, dorongan seksual yang sesuai, dan keseimbangan psikomotor (Guyton, 2014).

Lingkungan yang tenang dapat mengeliminasi neurotransmiter rasa tertekan, stres, ketegangan dan kecemasan sehingga menciptakan ketenangan, memperbaiki suasana hati (mood) dan menurunkan kegelisahan (Djohan, 2009). Tujuan dari pemberian terapi somatis isolasi adalah untuk memberikan lingkungan yang aman dan nyaman bagi pasien. Kondisi ini mampu menstimulasi neurotransmiter yang merangsang rasa nyaman, mengurangi rasa tertekan dan ketegangan pada pasien sehingga bisa menurunkan perilaku kekerasan.

\section{KESIMPULAN}

Implikasi

Hasil analisis data pengaruh terapi somatis isolasi terhadap perubahan perilaku kekerasan adalah terdapat pengaruh yang signifikan antara pemberian terapi somatis isolasi terhadap perubahan perilaku kekerasan pada pasien skizofrenia. Dalam pemberian terapi somatis isolasi, perawat dapat mempertimbangkan diagnosa medis pasien, status pasien baru atau dengan kasus rejatan, serta karakteristik lain seperti umur, jenis kelamin, pendidikan serta status perkawinan sehingga pelaksanaan observasi terhadap klien dapat berjalan secara optimal.

\section{Keterbatasan \\ Pada penelitian ini terdapat keterbatasan dalam penerapan terapi somatis, sehingga perlu disusun standar operasional prosedur (SOP) terapi somatis isolasi sesuai teori terbaru dan dapat digunakan sebagai pedoman dalam pelaksanaan tindakan tersebut. Untuk pengembangan asuhan keperawatan jiwa yang komprehensif maka dipandang perlu dilakukan penelitian lebih lanjut mengenai pengaruh terapi somatis isolasi terhadap perubahan perilaku kekerasan pada pasien skizofrenia baik dari segi jumlah sampel, karakteristik responden serta kriteria inklusi dan eksklusi yang membuat sampel menjadi lebih homogen.}

\section{DAFTAR PUSTAKA}

Amelia, D. R. (2013). Relaps Pada Pasien Skizofrenia. Malang : Jurnal Ilmiah Psikologi Terapan Universitas Muhammadiyah Malang Vol 1, No 1.

Aulya, A. (2016). Perbedaan Perilaku Agresif Siswa Laki-Laki Dan Siswa Perempuan. Padang : Jurnal Pendidikan Indonesia Universitas Negeri Padang Vol 2 No 1.

Bidang Perawatan RSJ Provinsi Bali. (2016). Indikator Mutu Bidang Keperawatan. Bangli (tidak dipublikasikan).

Direja, A. H. (2011). Buku Ajar Asuhan Keperawatan Jiwa. Yogyakarta: Nuha Medika.

Djohan. (2009). Psikologi Musik. Yogyakarta : Best Publisher.

Guyton, A.C., Hall, J.E. (2014). Buku Ajar Fisiologi Kedokteran Edisi 12. Jakarta : EGC

Howes, G. N. (2013). Use Of Seclusion For Managing Behavioural Disturbance in Patients vol. 19, 422-428. New 
Desak Made Ari Dwi Jayanti: Pengaruh Terapi Somatis Isolasi Terhadap Perubahan Perilaku Kekerasan Pada Pasien Skizofrenia

Zealand: Advances in Psychiatric Treatment Journal.

Keliat, B.A. (2014). Analisis Legal Aspek Dan Kebijakan Restrain, Seklusi Dan Pasung Pada Pasien Dengan Gangguan Jiwa. Jakarta : Jurnal Keperawatan FK UI.

Keliat. (2016). Keperawatan Kesehatan Jiwa. Jakarta : EGC.

Kementerian Kesehatan RI. (2013). Riset Kesehatan Dasar (Riskesdas) 2013. Jakarta: Kementerian Kesehatan RI.

.Kementerian Kesehatan RI. (2016). Peran Keluarga Dukung Kesehatan Jiwa Masyarakat. Jakarta: Kementerian Kesehatan RI.

Maramis. (2008). Catatan Ilmu Kedokteran Jiwa. Surabaya : Airlangga University Press.

Nusantari, N. N. (2017). Pengaruh Terapi Somatis Restrain Terhadap Penurunan Perilaku Kekerasan Pada Pasien Skizofrenia Di Rumah Sakit Jiwa Provinsi Bali. Skripsi Program Studi Ilmu Keperawatan STIKES Wira Medika PPNI Bali.

Prabowo, E. (2014). Konsep dan Aplikasi Asuhan Keperawatan Jiwa, Yogyakarta : Nuha Medika.

Prabowo. (2015). Buku Ajar Keperawatan Jiwa. Yogyakarta : Nuha Medika.

Rekam Medik Rumah Sakit Jiwa Provinsi Bali. (2017). Laporan Tahunan Rumah Sakit Jiwa Provinsi Bali. Bangli.

Saseno. (2013). Pengaruh Tindakan Restrain Fisik Dengan Manset Terhadap Penurunan Perilaku Kekerasan Pada Pasien Skizofrenia Di Ruang Rawat Intensif Bima Rumah Sakit Jiwa Grhasia. Yogyakarta : Jurnal Keperawatan Mersi vol. 4

Sira, I. (2011). Karakteristik Skizofrenia. Skripsi Program Studi Pendidikan Dokter FK Universitas Tanjungpura.

Stuart, G. W. (2013). Buku Saku Keperawatan Jiwa Edisi 5. Jakarta : EGC.

Valkama, A. K. (2010). The Use of Seclusion and Mechanical Restraint in Psychiatry. Finland : Journal of
Academic Dissertation University Of Tampere

Yosep, I. (2009). Keperawatan Jiwa. Bandung : PT Refika Aditama. 